\title{
The Influence of Family, Community, and Information Technology Supports on Empowerment of Diabetes Mellitus Patients Using SEM (Structural Equation Modelling)
}

\author{
Agus Heru Darjono ${ }^{1, *}$, Ujang Sumarwan ${ }^{2}$, Lilik Noor Yuliati $^{3}$, Hari Wijayanto ${ }^{3}$ \\ Institut Pertanian Bogor \\ Bogor Institute of Agriculture (IPB), Indonesia \\ *Corresponding author's email: agus.darjono [AT] gmail.com
}

\begin{abstract}
Diabetes mellitus (DM) is a chronic disease that has not yet been able to cure. Supports are needed by its patients in order to increase their empowerment to manage their chronic disease. This study aimed to analyze the influence of supports for the empowerment of DM patients. The analytical method used in this research is Structural Equation Model (SEM) with 330 respondents at 25 hospitals within JABODETABEK (Jakarta, Bogor, Depok, Tangerang, Bekasi) areas. The results of this study showed that family support, community support and information technology support influence the empowerment of DM patients.
\end{abstract}

Keywords---- support, empowerment, diabetes mellitus.

\section{BACKGROUND}

Chronic disease is a disease with a prolonged range of pain, time of suffering and play a role as the major cause of disability and death. Chronic illness causes inability to work, a decrease in quality of life, and a significant increase in direct and indirect medical costs (Morewitz 2006). The condition of chronic disease is the result of complex interactions between environmental, social, and genetic factors. Health care issues such as: smoking, being overweight, obesity, malnutrition, sedentary lifestyle, and genetics are some of the many factors associated with chronic disease. Racial, ethnic, gender, age and socio-economic gaps in health care are risk factors for chronic disease and also able to exacerbate the impact of chronic disease condition (Morewitz 2006).

Chronic disease is currently experiencing increased growth, complications of several diseases, increased health costs, and the current healing of the disease is focusing only on major diseases (Ministry of Health 2017). Chronic health problems are important parts of health care costs. Three chronic diseases that bear considerable costs are cardiovascular disease (including stroke), cancer, and diabetes. It can be seen in table 1 that the main cause of death is especially from chronic disease. The cost of these chronic diseases increases due to acute chronic complications and co-morbidity (disorders / diseases other than primary disease). Further effects, co-morbidity associated with chronic disorders can worsen disease outcomes and increase health care costs (Morewitz 2006). The lack of health insurance for Indonesian society limits access to rapid diagnosis and treatment and increases morbidity, mortality, and health care costs. If many people who do not have access to public health care, do not use preventive health services, it will delay them from obtaining health care, and it will depend on expensive emergency care services for the condition of primary medical care. The presence of these socioeconomic disparities results in higher health care costs than if people have access and use regular health care resources.

Table 1 The main causes of death derived from Indonesian sample registration system 2014

\begin{tabular}{|c|l|l|}
\hline No & Cause of Death & $\%$ \\
\hline 1 & Stroke & 21.1 \\
\hline 2 & Coronary heart disease & 12.9 \\
\hline 3 & Diabetes mellitus with complications & 6.7 \\
\hline 4 & Pulmonary tuberculosis & 5.7 \\
\hline 5 & Hypertension with complications & 5.3 \\
\hline 6 & Chronic obstructive pulmonary disease & 4.9 \\
\hline 7 & Heart disease & 2.7 \\
\hline 8 & Traffic accidents & 2.6 \\
\hline 9 & Pneumonia & 2.1 \\
\hline 10 & Diarrhea and other digestive tract infections & 1.9 \\
\hline
\end{tabular}

Source: BPJS Kesehatan (2016) 
People diagnosed with chronic diseases must adjust to the demands of the disease themselves, as well as care for the condition. Diseases can affect a person's mobility and independence, and change the way a person lives, sees him / herself, and / or relates to others (Morewitz 2006). The main risk factors for non-communicable diseases are behavior, lifestyle, globalization and other social problems.

Chronic diseases can cause catastrophic diseases. Catastrophic diseases have the following characteristics i) the diseases are high cost and their complications can be life-threatening; ii) degenerative, old manifestations, not realized; iii) treatment with special expertise or sophisticated medical devices; iv) lifelong control and health services; and v) absorption of the largest health claims (Heniwati, et al. 2016). Some examples of catastrophic diseases include i) potentially chronic and complicated hypertension causing stroke or heart attack, coronary heart disease that requires comprehensive handlers; ii) chronic kidney failure which causes permanent dialysis; iii) hypercholesterolemia that requires long-term medication, iv) diabetes mellitus that requires continuous medication related to chronic complications and v) cancer or other tumors (Heniwati et al. 2016).

One of those chronic and catastrophic diseases is diabetes mellitus (DM). DM is a chronic disease that will be carried out for life. Management of this disease requires the participation of doctors, nurses, nutritionists, and other health workers (PERKENI 2015). Patients and families also have important roles, so it is necessary to get education to provide an understanding of transmission of the disease, prevention, complication, and management of diabetes mellitus (PERKENI 2015). Self-care interventions for chronic disease sufferers in the form of patient empowerment programs have been proven to improve mental health, doctor-patient communication, healthy eating, and patient self-efficacy, although the outcome measures differrent results (WHO 2008; IPPR 2014; Barr et al 2015; EPR 2015). The implementation of patient empowerment is important in the health care of chronic diseases, especially Diabetes Mellitus.

Patient empowerment can be conceptualized as a process that is achieved through patient-centered care, or to the patient as a result, and includes elements relating to the role of patients and health professionals, joint decision making, patient self-efficacy and coping (Holmstrom and Roing 2010). Loane (2014) further states that traditional asymmetric relationships between patients and doctors are challenged by a new form in which health consumers are empowered and able to work in partnership with medical service providers in the sustainable management of chronic diseases.

According to Tol (2012) empowerment is a psychosocial self-efficacy. Health professionals and researchers have introduced 'self-empowerment' as a key element in managing chronic diseases. In chronic disease such as diabetes mellitus empowerment implies an approach attempted to improve the ability of patients to actively understand and influence their own lives and health status. It seems that patients with chronic diseases are empowered to manage chronic diseases by actively seeking information and increasing their knowledge. With regards to health services, MacStravic (2000) goes further by indicating that the empowerment of patients can get more health benefits and is better managed by the care providing organizations than what used to be provided for the ordinary consumers. This is because it has the potential to force patients to make their own choices and take risks, and spend more time and money caring for themselves and their family members.

Previous studies such as Hartini (2012)'s study also stated that family, self, medical personnel and community support affected the recovery of the patients of coronary heart disease. Previous studies state that medical personnels supported patient empowerment (Ouchsan et al. 2006; Simanjuntak 2014; Nursasi 2015), internal communication influenced empowerment (Elinger 2010; Nursasi 2015) and perceptions of the quality of physicians affected patients' empowerment (Camacho et al. 2014). Nursasi (2015)'s Study also stated that the environmental community and the community as parts of the patient's social life affected patients' health care. Patients undergoing treatment desperately needed family support and social support. Similar studies were also conducted by Simanjutak (2014) on social support (Anderson 2006) and the influence of information access (Nord et al. 2016; Labraque et al. 2013). Various previous studies had become references to comprehensively assess family, community and technological supports to influence empowerment. This study attempted to combine these supports.

\section{METHODOLOGY}

This study used descriptive correlational and aimed to explain, describe, and relate between the variables under study. Correlational descriptive was conducted to identify the factors of family, community and technology support that influenced patients' empowerment. Survey research was conducted at Government and Private Hospitals within the JABOTABEK areas. Respondents were 330 DM patients from 25 hospitals.

The survey used questionnaires which were tested for their validity and reliability beforehand. Validity test was carried out before processing data and showed the accuracy and validity of the instrument in measuring the variables to be measured. The validity test used was product moment correlation test. Validity test was done by conducting correlation test between the scores of each item question with the total score for each variable with percent allowance of $(5 \%)$ and free degree of $n-2=28$, it was obtained that $r$-table value was 0.361 . If the value of $r$-count was $>0.361$ then items were valid and could be used in the research, while to the items that were invalid, i.e. in forms of questions or statements, then their composition of words or sentences were remodified so the respondents could understand them better. 
Reliability test was used to determine the consistency of the measuring instrument, whether the measuring instrument used was consistent if the repetition of measurement was done. The method used in the reliability test of this study was the Alpha method (Cronbach's). The real test was carried out at a real level of 0.05 , meaning that the questions posed to the reader were said to be reliable since the alpha value was greater than $r$ critical ( $r$ count).

The next testing was done by using Structural Equation Modeling (SEM) which aimed to test statistical models that were usually in form of causal models. The goodness of fit of SEM models must meet the following criteria as cited in Table 2:

Table 2 Size of the models of goodness of fit criteria

\begin{tabular}{|c|c|}
\hline $\begin{array}{l}\text { Size of Goodness of } \\
\text { Fit }\end{array}$ & Level of Goodness of Fit that can be accepted \\
\hline Chi-square $\left(\chi^{2}\right)$ & $\begin{array}{l}\text { The smaller the better. A small chi-square value is used to make Ho }: \sum=\sum(\theta) \text {, } \\
\text { not rejected }\end{array}$ \\
\hline Probability & $\geq 0,05$ \\
\hline GFI & $\begin{array}{l}\text { The higher the better. GFI } \geq 0.90 \text { is } \text { good-fit, } \\
0,08 \leq \mathrm{GFI}<0,90 \text { is marginal fit }\end{array}$ \\
\hline AGFI & $\begin{array}{l}\text { The higher the better. AGFI } \geq 0,90 \text { is good fit, } \\
0,80 \leq \mathrm{AGFI}<0,90 \text { is marginal fit }\end{array}$ \\
\hline RMR & $\begin{array}{l}\text { Average residual between observed matrices and estimation results. } \\
\mathrm{RMR} \leq 0,05 \text { is } \text { good-fit }\end{array}$ \\
\hline RMSEA & $\begin{array}{l}\text { The average difference per degree of freedom that is expected to occur in the } \\
\text { population and not in the sample. } \\
\text { RMSEA } \leq 0,08 \text { is good fit, } \\
\text { RMSEA } \leq 0,05 \text { is close fit. }\end{array}$ \\
\hline
\end{tabular}

\section{DISCUSSION AND RESULTS}

Supports factors were measured in three dimensions, namely family support, community support or friend support, and information technology support. These three dimensions were significantly the right dimensions to measure the supports factors. This was supported by a test which obtained $\mathrm{p}$ value $<0.05$ for each dimension of support. The variables used in this study were: i) environmental and community support (family support, community support, and information technology support); and ii) patient empowerment (patient knowledge, patient control, and patient participation).

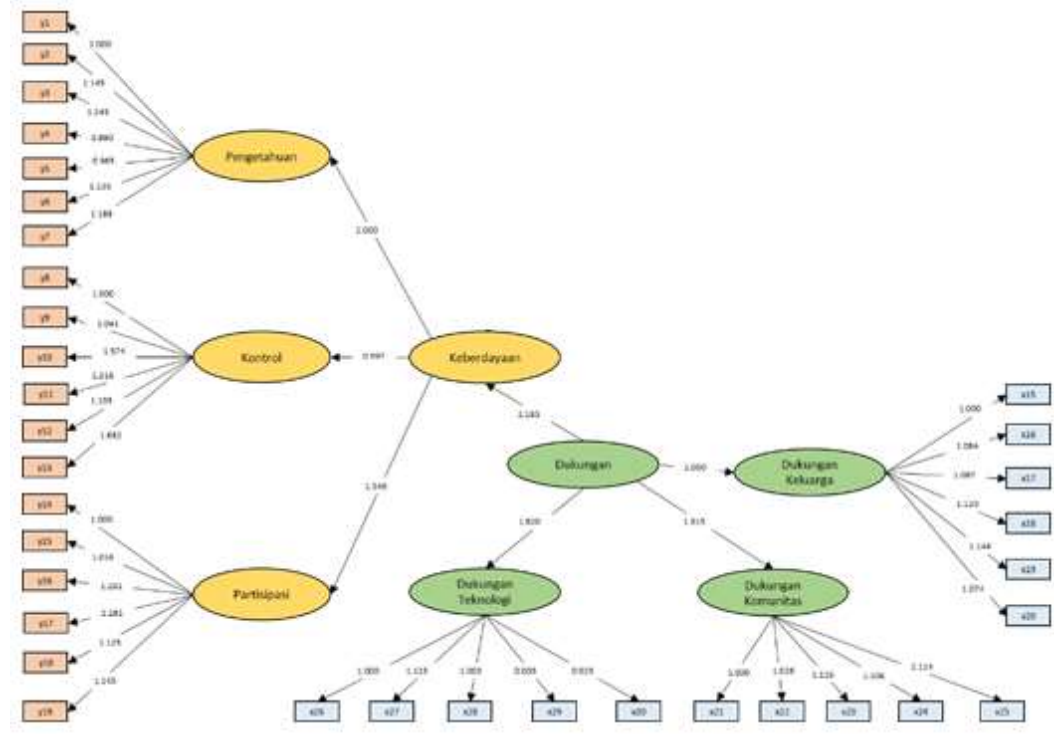

Path Diagram of Structural Equation Model of the Influence of Supports for Patients' Empowerment

Patient empowerment was a variable observed from several dimensions, namely patient knowledge, patient control, and patient participation. The dimension that had the biggest contribution or influence on patient empowerment was patient participation which was equal to 1.346 , patient knowledge was 1.000 , and patient control was 0.997 . These three dimensions had significant effects on patients' empowerment ( $\mathrm{p}$ value $=0.000$ ) as seen in table 4 . The results of this analysis were presented in the following table. In contrast, Drye (2008) used consumer empowerment with consumer trust, fairness, commitment and involvement. 
Table 3 Effect of knowledge, control, and participation on empowerment

\begin{tabular}{|l|l|l|l|}
\hline & Coefficient & $\begin{array}{l}\text { Standards of } \\
\text { Errors }\end{array}$ & p Value \\
\hline Patients' Knowledge & 1.000 & - & - \\
\hline Patients' Control & 0.997 & 0.166 & $0.000^{* * *}$ \\
\hline Patients' Participation & 1.346 & 0.193 & $0.000^{* *}$ \\
\hline
\end{tabular}

Patients' knowledge was measured through 7 indicators. These seven indicators significantly $(\mathrm{p}=0.000)$ described or truly represented the knowledge of the patients. Patients' control consisted of 6 indicators. This dimension measured the patients' activities in controlling their own illness. Things that were measured in the patients' control dimensions were the habit of the patients in examining the disease independently, regulating the pattern of life, taking the initiative to notify the doctor when signs of disease appear, and following the treatment that had been suggested by the doctor. Patients' participation was measured by 6 indicators. This dimension measured patients' participation in the process of healing the disease. The things measured in the dimensions of patients' participation were preparation for consulting a doctor, effort in seeking information about diseases and treatment, patient initiative in expressing opinions to doctors regarding treatment plans. It was seen in table 4 the indicators and results of validity and reliability tests.

Table 4 Indicators, validity and reability tests

\begin{tabular}{|c|c|c|}
\hline Dimension & Indicator & Remark \\
\hline \multirow{7}{*}{$\begin{array}{l}\text { Patients' } \\
\text { Knowledge }\end{array}$} & Y1. Understand the information about DM treatment & \multirow{7}{*}{$\begin{array}{l}\text { Valid } \\
\text { and } \\
\text { reliable }\end{array}$} \\
\hline & Y2. Understand DM health information in written form & \\
\hline & $\begin{array}{l}\text { Y3. Understand DM health information from websites and health } \\
\text { related media }\end{array}$ & \\
\hline & Y4. Understand the impact of diabetes and lifestyle adaptation & \\
\hline & Y5. Understand the warning symptoms of DM disease & \\
\hline & Y6. Understand the development of diabetes & \\
\hline & Y7. Get the information about DM treatment options & \\
\hline \multirow{6}{*}{$\begin{array}{l}\text { Patients' } \\
\text { Control }\end{array}$} & Y8. Regularly check the health status of diabetes mellitus & \multirow{6}{*}{$\begin{array}{l}\text { Valid } \\
\text { and } \\
\text { reliable }\end{array}$} \\
\hline & Y9. Tell the doctor / nurse if the sign of DM is found & \\
\hline & Y10. Conduct regular checks on themselves & \\
\hline & Y11. Regulate diet and lifestyle & \\
\hline & Y12. Follow the prescribed medication & \\
\hline & Y13. Conduct and document check ups / examinations & \\
\hline \multirow{6}{*}{$\begin{array}{l}\text { Patients' } \\
\text { Participation }\end{array}$} & Y14. Request to receive medical test result / medical report & \multirow{6}{*}{$\begin{array}{l}\text { Valid } \\
\text { and } \\
\text { reliable }\end{array}$} \\
\hline & Y15. Make questions submitted to the doctor & \\
\hline & Y16. Look for additional information / other opinions & \\
\hline & Y17. Convey opinions in determining treatment & \\
\hline & Y18. Doctor / nurse should consider the opinion of the patients & \\
\hline & $\begin{array}{l}\text { Y19. Have treatment plans based on the opinion of the doctor / } \\
\text { nurse and also based on personal views }\end{array}$ & \\
\hline
\end{tabular}

Supports were factors that were observed and deemed to have influences on patients' empowerment in addition to the role of health care providers. The three dimensions used to measure supports were family support, community / friend support, and information technology support. These three dimensions had significant effects on the supports' variables (value $\mathrm{p}=0.000$ ). The dimension that gave the biggest influence or contribution to supports was the dimension of information technology support with the magnitude of the influence / coefficient of 1.346, then followed by community / friend support of 1.315, and family support of 1.000. The results of the analysis containing the coefficient values, standards of errors, and significance tests (real tests) were presented in Table 5. A study that was conducted by Al-Kahfi (2016) showed that most types of diabetes mellitus patients had high self-efficacy by getting family support to prevent foot diabetic disease. There was a relationship between self-efficacy and family support for prevention of foot diabetic disease (Al-Kahfi 2016).

Table 5 Influence of family support, community / friend support, and information technology support for supports

\begin{tabular}{|l|l|l|}
\hline Dimension & Coefficient & $\mathrm{p}$ value \\
\hline Family Support & 1.000 & - \\
\hline Community / Friend Support & 1.315 & $0.000^{* *}$ \\
\hline Information Technology Support & 1.820 & $0.000^{* *}$ \\
\hline
\end{tabular}


Family support was manifested in the form of family attitudes, family actions and family acceptance of sufferers who are sick. Family members viewed that supportive people were always ready to provide help and assistance if needed. Family support was a latent variable consisting of six indicators. Community / friend support was measured by 5 indicators. The things measured in this dimension were the provision of knowledge about diseases and treatment by fellow patients suffering from disease, giving motivation in complying with the rules of treatment among fellow patients, willing to remind each other to change their lifestyle. Information technology support was measured from five indicators. The variables' indicators above reflected how the perceptions of respondents in participating in seeking information through information technology support in the form of internet and social media available both from health care providers and others, as shown in table 6.

Table 6 Indicators, validity and reliability tests of supports

\begin{tabular}{|c|c|c|}
\hline Dimension & Indicator & Remark \\
\hline \multirow{6}{*}{$\begin{array}{l}\text { Family } \\
\text { Support }\end{array}$} & X15. Family wants to listen to DM patients' complaints & \multirow{6}{*}{$\begin{array}{l}\text { Valid and } \\
\text { reliable }\end{array}$} \\
\hline & X16. Family values the patients like before they are sick & \\
\hline & X17. Family wants to take the time to assist & \\
\hline & X18. Family supports and encourages treatment & \\
\hline & $\mathrm{X} 19$. It is easy to ask for help from the family & \\
\hline & X20. Family reminds to regulate on diet, lifestyle, and medicine & \\
\hline \multirow{5}{*}{$\begin{array}{l}\text { Community } \\
\text { Support }\end{array}$} & X21. Community / friend informs DM knowledge & \multirow{5}{*}{$\begin{array}{l}\text { Valid and } \\
\text { reliable }\end{array}$} \\
\hline & X22. Community / friend provides information on DM services & \\
\hline & X23. Community / friend motivates to maintain DM compliance & \\
\hline & $\begin{array}{l}\text { X24. Community / friend reminds to maintain diet, take the drugs } \\
\text { that need to be consumed and keep on balanced lifestyle }\end{array}$ & \\
\hline & X25. Community / friend exchanges information about DM & \\
\hline \multirow{5}{*}{$\begin{array}{l}\text { Information } \\
\text { Technology } \\
\text { Support }\end{array}$} & $\begin{array}{l}\text { X26. Patients are used to looking for information from the media } \\
\text { regarding DM }\end{array}$ & \multirow{5}{*}{$\begin{array}{l}\text { Valid and } \\
\text { reliable }\end{array}$} \\
\hline & $\begin{array}{l}\text { X27. Patients are trying to find information sources for DM } \\
\text { disease }\end{array}$ & \\
\hline & $\begin{array}{l}\text { X28. Patients are more comfortable to look for information } \\
\text { through the internet or social media }\end{array}$ & \\
\hline & $\begin{array}{l}\text { X29. Patients prefer to ask directly to others in seeking } \\
\text { information* }\end{array}$ & \\
\hline & $\begin{array}{l}\text { X30. The existence of information technology, easy to get } \\
\text { information. }\end{array}$ & \\
\hline
\end{tabular}

*) invalid

The effects of the supports factors on patients' empowerment were analyzed by using SEM (Structural Equation Modeling). The Goodness of Fit test of the model was based on CFI and TLI which stated that the model was classified as good fit because the resulting value was greater than the cut point of 0.90 . The resulting RMSEA value was smaller than 0.08 so the model was also declared fit while the SRMR value generated was 0.083 which was categorized as "moderate" because it approached the model's feasibility limit value of 0.08 . The test results for the Goodness of Fit of the model were shown in Table 9 below.

Table 7 Testing the Goodness of Fit of the patients' empowerment model by using SEM

\begin{tabular}{|l|l|l|l|}
\hline Model Goodness of Fit Test & Value & Cut Point & Remark \\
\hline Chi-Square & 0.000 & $\mathrm{P} \geq 0.05$ & Model does not fit \\
\hline Comparative Fit Index (CFI) & 0.919 & CFI $\geq 0.90$ & Good fit \\
\hline Tucker-Lewis Index (TLI) & 0.901 & TLI $\geq 0.90$ & Good fit \\
\hline RMSEA & 0.057 & RMSEA $\leq 0.08$ & Good fit \\
\hline SRMR & 0.083 & SRMR $\leq 0.08$ & Moderate fit \\
\hline
\end{tabular}

The results of the analysis showed that supports had significant effects on patients' empowerment ( $\mathrm{p}$ value = 0.031). The magnitude of the influence of supports for patient empowerment was indicated by the coefficient value that was equal to 2.183. Coefficient values, standards of errors, and significance test values or real tests were displayed in Table 8 . 
Table 8 Influence of Supports for Patients' Empowerment

\begin{tabular}{|l|l|l|}
\hline Variable & Coefficient & p value \\
\hline Supports & 2.183 & $0.031^{*}$ \\
\hline
\end{tabular}

Based on the results of the analysis and the discussion presented above, the managerial implications that can be formulated were i) to provide health services to create remote monitoring online, on-line consultations and information platforms (e-health) which are easily accessible and affordable for all, ii) to create an environment that supports participation, which is more communicative, and to provide more trainings to improve the communication skills of health service providers so as to increase patients' participation; iii) patients or family members should be involved as community members and be the part of a sharing community and iv) government should open a 24-hour online consultation program for patients' empowerment.

\section{CONCLUSIONS AND SUGGESTIONS}

Conclusion of this research which used SEM model was it was known that the supports factors consisting of family support, community support and information technology support had significant inluences on patients' empowerment. Suggestions for further research regarding this study is the researcher should more clearly distinguish the types of hospitals referred to by patients with diabetes mellitus and they should conduct a more in-depth study to government policies that support patients' empowerment.

\section{REFERENCES}

- Al-kahfi R, Palimbo A, Marlina. 2016. Pengaruh efikasi diri dan dukungan keluarga terhadap pencegahan kaki diabeteik pada pasien rawat jalan diabetes melitus tipe 2 di RSUD Dr H Moch Ansari Saleh Banjarmasin. Dinamika Kesehatan. 7(2):332-346

- Anderson RE, Huang WR. 2006. Empowering salesperson: personal, managerial and organizational perspectives. Psychology \& Marketing. 23(2): 139-159.

- $\quad$ [BPJS Kesehatan] Badan Penyelenggaran Jaminan Sosial Kesehatan. 2016. Laporan pengelolaan Program Tahun 2016 dan Laporan Keuangan Tahun 2016. Jakarta (ID): BPJS Kesehatan.

- _. _. 2017. Kedudukan dan Status Kelembagaan BPJS Kesehatan. Jakarta (ID): BPJS Kesehatan

- Camacho N, Jong M, Stremersch S. 2014. The effect of customer empowerment on adherence to expert advice. Intern J. of Rsearch in Marketing. http://dx.doi.org/10.1016/j.ijresmar.2014.03.004. Article in press

- $\quad$ [EPR] European Patient Forum. 2015. Empowered patient are an asset tp society. Conference report 20-21 May 2015. Belgia(BE): EPR.

- Hartini MCS. 2002. Dukungan diri, keluarga dan masyarakat serta pengaruhnya terhadap pemulihan penyakit jantung koroner bagi pasien pria di R.S Pelni Jakarta. [Tesis]. Bogor (ID): Insitut Pertanian Bogor.

- Heniwati, Thabrany H. 2016. Perbandingkan klaim penyakit katastropik peserta jaminan kesehatan nasional di provinsi DKI Jakarta dan Nusa Tenggara Timur tahun 2014. Jurnal Ekonomi Kesehatan Indonesia. 1(2): 88-97

- Holmstrom I, Roing M. 2010. The relation between patient-centeredness and patient empowerment: a discussion on concepts. Patient Education and Counseling. 79:167-172.

- $\quad$ [IPPR] Institute for Public Policy Research. 2014. Patient in Control Why People with Long-term Conditions Must be Empowermed. London (UK): IPPR.

- [KEMENKES] Kementerian Kesehatan RI. 2016. Profil Kesehatan Indonesia Tahun 2016. Jakarta (ID): Kemenkes.

- _ _ 2017. Laporan Kinerja Kementerian Kesehatan Tahun 2017. Jakarta (ID): Kemenkes.

- _ _ 2017. Rencana Aksi Program Sekretariat Jenderal Tahun 2015-2019 Revisi. Jakarta (ID): Kemenkes

- $\quad$ Labrrecque LI, Esche J, Mathwick C, Novak TP, Hofacker CF. 2013. Consumer power: evolution in the digital age. Journal of Interactive Marketing. 27: 257-269.

- Loane SS, D'Alessandro S. 2014. Empowered and knowledgeable health consumers: the impact of online support groups on the doctor-patient relationship. Australasian Marketing Journal. 22:238-245.

- MacStravic S. 2000. The downside of patient empowerment: while consumers and managed care alike applaud the trend toward empowering patients, this shift has placed new and sometimes overwhelming burdens on consumers. Health Forum Journal. 30:1.

- Morewitz SJ. 2006. Chronic Diaseases and Health Care: New Trends in Diabetes, Arthritis, Osteoporosis, Fibromyaglia, Low Back Pain, Cardiovascular Disease, and Cancer. New York (US): Springer 
- Nord JH, Lee TR, Cetin F, Atay O. 2016. Examining the impact of social technologies empowerment and economic development. International Journal of Information Management. 36:1101-1110.

- Nursasi AY. 2015. Efektivitas model keberdayaan perawat, kader, keluarga, dank lien (P2K3) terhadap kemandirian klien tuberculosis paru dalam melakukan perawatan diri di kota Depok. [Disertasi]. Depok (ID): Universitas Indonesia.

- Ouchsan R, Sweeney J, Johnson L. 2006. Customer empowerment and relationship outcomes in healthcare consultations. European Journal of Marketing. 40(9/10): 1068-1086.

- [PERKENI] Perkumpulan Endokronologi Indonesia. 2015. Konsesus Pengelolaan dan Pencegahaan Diabetes Melitus Tipe 2 di Indonesia 2015. Jakarta (ID): PERKENI

- Simanjuntak M. 2014. Tingkat keberdayaan dan strategi keberdayaan konsumen. [Disertasi]. Bogor (ID). Institut Pertanian Bogor.

- Simanjuntak M, Yulianti LN. 2015 Pengembangan Indeks Keberdayaan Konsumen. ISBN: 978- 602-96826-4-9

- _ 2016. Pemetaan Indeks Keberdayaan Konsumen 2016 [Laporan]. Bogor (ID): Institut Pertanian Bogor.

- _ 2016. Indeks Keberdayaan Konsumen di 13 Provinsi di Indonesia 2016 [Laporan]. Bogor(ID): Institut Pertanian Bogor

- Sumarwan U. 2011. Prilaku Konsumen: Teori dan Penerapannya dalam Pemasaran. Jakarta (ID): PT Ghalia Indonesia

- Tol A, Shojaeezadeh D, Sharifirad G, Alhani F, Tehrani M. 2012. Determination of empowerment score in type 2 diabetes patients and its related factors. J Pak Med Assoc. 6(1): 16-20.

- Valentijn PP, Schpman SM, Opheij W, Bruijnzeels MA. 2013. Understanding integrated care: a comprehensive conceptual framework based on the integrative functions of primary care. International Journal of Integrated Care. 13:1-12.

- [WHO] World Health Organization. 2002. Innovative care for chronic conditions. Geneva (SZ): WHO

- [WHO] World Health Organization. 2008. Where are the patients in decision-making about their own care? Denmark (DK): WHO

- _. 2013. Exploring patient participation in reducing health care related safety risk. Copenhagen (DK): WHO

- _ _ 2012. Indonesia: WHO Statistical Profile. New York (US): WHO 